Article

\title{
Comparative Intergovernmental Politics: CETA Negotiations between Canada and the EU
}

\author{
Valerie J. D’Erman \\ Department of Political Science and European Studies Program, University of Victoria, Victoria, V8W 2Y2, Canada; \\ E-mail: vjderman@uvic.ca
}

Submitted: 21 January 2016 | Accepted: 15 March 2016 | Published: 11 August 2016

\begin{abstract}
The Comprehensive Economic and Trade Agreement (CETA) between Canada and the European Union (EU) required long-term negotiations between two major polities of the industrialized world. During the negotiations, Canada acquiesced to the EU's demand that Canadian provinces participate directly in discussions, setting an important precedent in the dynamics of Canadian external trade. This paper examines the dynamics of intergovernmentalism in the policy area of external trade within the settings of the Canadian provinces and the EU member states, and uses the findings to suggest that in this realm the EU is a stronger example of federal synthesis of decision-making than is Canada. This is significant because it contradicts many established theories of federalism within political science, and implies that the EU could become a strong source of normative example for federal-style polities in the globalized world. As well, the strength of the EU's single market lends credence to the institutions embedded within the supranational polity, and gives the EU significant normative power as a prototype for other experiments in regional integration.
\end{abstract}

\section{Keywords}

Canada-EU relations; European integration; federalism

\section{Issue}

This article is part of the issue "Supranational Institutions and Governance in an Era of Uncertain Norms", edited by Russell Alan Williams (Memorial University, Canada) and Reeta Tremblay (University of Victoria, Canada).

(C) 2016 by the author; licensee Cogitatio (Lisbon, Portugal). This article is licensed under a Creative Commons Attribution 4.0 International License (CC BY).

\section{Introduction}

Regional integration, whether in the form of free trade agreements or political alliances, is increasingly becoming a tool used by countries and markets to respond to the challenges of globalization. The Comprehensive Economic and Trade Agreement (CETA) brokered between Canada and the European Union (EU) and tentatively finalized, represents the largest free trade agreement in the wealthy industrialized world to date. 'Largest', in this sense, refers to the sizes of the combined Canadian market and EU Single Market, as well as the scope of the areas under agreement. The estimated value of combined international trade is approximately 61.6 billion (European Commission, 2013); in addition, the agreement targets the removal of non-tariff barriers (i.e., special licensing, regulatory regimes, and anti-dumping measures) rather than conventional trade barriers (i.e., customs tariffs, quotas), many of which were already significantly low between Canada and the EU. ${ }^{1}$ Discussions on closer economic partnership began at the 2007 EU-Canada Summit in Berlin, where leaders agreed to complete a joint study. After publication of the joint study in 2008, leaders agreed to pursue negotiations toward a comprehensive

\footnotetext{
${ }^{1}$ As stated in House of Commons (2011), which mentions that "the average tariffs imposed by Canada and the EU on imports were already very low and that there were very few traditional trade barriers between Canada and the EU." This is heightened when assessing tariffs in a comparative context: Canada and the EU, among other developed countries, demonstrated increasingly low tariff barriers following the WTO Doha Round (World Trade Organization, International Trade Centre, \& United Nations Conference on Trade and Development, 2015).
} 
economic agreement. As of October 2013, Canadian Prime Minister Stephen Harper and European Commission President José Manuel Barroso agreed in principle to the resulting package of CETA negotiations (Government of Canada, 2013). ${ }^{2}$ Prior to CETA, both Canada and the EU have each successfully negotiated other free trade agreements with other significant economic areas (most notably, Canada within NAFTA, and the EU's agreement with South Korea). However, the scope of CETA's provisions for non-trade barriers-including, but not limited to, services, investment, and public procurement-and the political and economic impacts of trans-Atlantic free trade are thus far unparalleled. ${ }^{3}$

Due to the size, scope, and political precedence of CETA, an examination of how the two sides reached the agreement to date is worthwhile for understanding the negotiation dynamics between two wealthy-and decentralized-entities. Comparing the interaction between the provinces and the federal government in Canada with the interaction between the EU Commission and the member states of the EU, holds the potential to offer substantive implications on the EU's ability to set norms related to intergovernmental dynamics, as well as implications for the study of federalism and federal types of governance. In particular, many federalist scholars assert that Canada provides a solid prototype of a federal nation with divided powers between central and regional governments, while the EU remains a supranational experiment that mimics some federal-like processes of governance but ultimately remains a collection of distinct nation-states sharing a confined realm of shared economic (and, to some extent, political) decisionmaking (see, for example, Moravscik, 2007). Other scholars argue that while the conventional national form of federation is absent from the EU, the overarching application of shared authority between the EU institutions and member states in different policy areas is indeed applicable toward categorizing the EU within a comparative framework of federal-style polities (examples include Burgess, 2012; Elazar, 1995; Hueglin, 2013). This is justified not only by detailed study of EU governance, but also with the consideration that all federations have significant differences from each other, and yet all still offer import into the central idea of harmony in shared rule between different regions. Beyond the categorization of federalisms, the negotiation dynamics that unfolded during the build-up to CETA's finalization suggest that the $\mathrm{EU}$ is not just a strong

2 As of December 2015, the CETA agreement is finalized "in principle". This means that translation into all EU languages still needs to take place, as well as ratification among all EU member states and Canadian actors.

${ }^{3}$ At the time of writing, a Transatlantic Trade and Investment Partnership (TTIP) is in the early stages of discussion between the EU and the U.S. market, but is also a strong normative default example for how other markets-regional or national-might choose to govern themselves during international negotiations.

The process of CETA in Canada received a great deal of coverage by municipal governments, news sources and business groups-perhaps logically, as the EU is Canada's $2^{\text {nd }}$ large trading partner and represents Canada's second most important source of foreign direct investment. The EU represents $9.5 \%$ of Canada's total external trade (Government of Canada, 2013). At various points during CETA negotiations, provincial authorities and municipal governments levelled criticism at the federal government in Ottawa for conducting the negotiations with a lack of transparency and consultation. Provincial actors demanded more inclusion during negotiation as individual entities who sought to calculate their respective gains and losses in a potential free trade agreement with such a large and competitive market. By contrast, within the EU, there was relatively minimal coverage of CETA in Brussels and within most member states (with some important exceptions, outlined below). Economics alone can explain this in part: Canada is the EU's $12^{\text {th }}$ trading partner, representing $1.8 \%$ of the EU's total external trade (European Commission, 2013). This asymmetry of trade balance between the two entities offers one intuitive explanation for the differential level of interest; simply put, as the EU had more leverage through which to conduct negotiations, there was arguably less provocation of insecurity, or even interest, among EU member states. This paper argues, however, that economics and leverage alone do not account for a full explanation of why internal negotiating dynamics in Canada were more contentious than within the EU. Instead, this paper argues that the delineation of competences within the EU with regard to international trade made for a more streamlined process, in contrast to the Canadian form of provincial-federal involvement in negotiations. The EU member states are not involved directly in the negotiations because they have authorized the European Commission to negotiate on their behalf, whereas the Canadian provinces and territories played a more proactive role than do the EU member states in the ongoing negotiations toward a CETA (House of Commons, 2011). This difference has two implications: first, institutional differences matter, in that the organization of delegation and responsibility had potentially more impact on resulting agreements than the idea of difference between a province and a country; second, the area of international trade competency offers a direct contrast to the intuitive hypothesis of which political entity behaves more like a federation. The EU-which is not a single country and remains comprised of very distinct European countries-has more integration between regional and central levels with regard to trade negoti- 
ations than does Canada, which instead provides an example of sharper debates between the provincial and federal levels. The changes to provincial involvement in Canada during CETA negotiations point to the ability of the EU to export norms of intergovernmentalism.

The next section of the paper provides a brief overview of the CETA agreement from its inception, as well as a brief overview of the main tenants of federal theories. This is followed by a summary of internal negotiation dynamics within Canada and the EU, respectively. The summary includes a description of how federal-provincial processes operate within Canada with respect to external trade, as well as how the EU Commission interacts with EU member states in developing external free trade agreements. Following this is a comparative analysis of how each governing entity accommodates regional interests, attending to an overarching conception of federalism and centralregional dynamics. The conclusion summarizes the main findings and offers implications for future research in comparative federalism between Canada and the EU, and for the ability of the EU to export its own institutional norms.

\section{The Evolution of the Canada-EU Agreement}

Prior to the current agreement 'in principle', the history of Canada-EU/EC trade relations dates back to the 1976 Framework Agreement for Commercial and Economic Cooperation. This was essentially an institutional framework for cooperation in trade and regulatory harmonization, and marked the first large-scale agreement for the EU with an industrialized country. In 1998 the two entities established a customs cooperation agreement, a veterinary agreement, and a number of sectoral mutual recognition agreements. All of these developments paralleled separate developments the EU had concurrently reached with the U.S. (Woolcock, 2011, p. 27).

In 2004, discussions began on the idea of a larger bilateral agreement that would bring in a much larger degree of market access in areas still subject to regulatory barriers, such as (but not limited to) financial services, intellectual property rights issues, and public procurement. The EU stalled this effort-then called the Trade and Investment Enhancement Agreement (TIEA) - in 2006 after three rounds of negotiations failed to reach an agreement. The main reasons given for the stalled TIEA were the desire to wait for a successful result at the Doha Round of World Trade Organization (WTO) in the hopes that WTO negotiations would clarify some of the issues that had arisen over the course of TIEA discussions (Gauthier \& Holden, 2011, p. 4), and the EU's stated desire to have the Canadian provinces included in any agreement as a device of pre-commitment: "As EU liberalizing measures reach down below regional/provincial level and into the local level within the EU, the Commission sought broad reciprocity that the Canadian federal government could not deliver" (Woolcock, 2011, p. 27).

In 2007, the Quebec Premier Jean Charest, along with key EU leaders, pushed for re-opening discussions on stronger economic and political ties (Hübner, 2011, p. 3). The Government of Canada and the European Commission published a joint report in 2008, "Assessing the costs and benefits of a closer EU-Canada partnership". The purpose of the report was to examine the existing tariff and non-tariff barriers between the two blocs in order to assess the effects of removing or heavily reducing such barriers. The more contentious non-tariff barriers included labour mobility, government procurement, intellectual property rights, telecommunications and electronic commerce, along with regulatory cooperation in a number of other areas. The study also identified how deeper partnership could enhance bilateral cooperation in areas such as science and technology, energy, and the environment (European Commission \& Government of Canada, 2008, pp. ii-iii). Some of the key findings of the study predicted long-term macro-economic increases in real GDP of $0.02-0.03 \%$ for the EU and $0.18-0.36 \%$ for Canada, with potentially higher figures when factoring in investment gains. At the sectoral level, the study predicted the greatest gains in output and trade to be stimulated by services liberalization and by the removal of tariffs applied on sensitive agricultural products (European Commission \& Government of Canada, 2008, pp. 167-171).

Formal negotiations began in May 2009 and concluded in October 2013. The global financial crisis provided a backdrop impetus during this time period: for the EU, gains in trade from reduced barriers would provide revenue; for Canada, the need to diversify economics away from disproportionate dependence on the U.S. market became paramount. Major issues during the course of negotiations included (but were not limited to) beef and pork, cheese and dairy, public procurement procedures, pharmaceutical drugs, and copyright provisions. ${ }^{4}$ Prime Minister Harper and EU President Barroso stated in 2013 that the deal would likely be in place by 2015, after the text had been translated into all 24 languages of the EU and had been ratified by EU member states as well as Canada's provinces and territories (Waldie, 2013). News sources and public announcements concerning the deal 'in principle' hailed the CETA as a historic agreement for the depth of areas covered under an international free trade agreement. For Canada in particular, the agreement provided a notable precedent of the involvement of sub-national governments in international negotiations-one which

\footnotetext{
${ }^{4} \mathrm{~A}$ detailed overview of the scope of issues and debates over specific sectoral areas is beyond the scope of this paper. For more detail see Woolcock (2011).
} 
not only created a visible role for provincial interests, but also helped clarify the barriers between provinces that could impede commerce (Finbow, 2013, p. 3).

\section{Federal Theories, in Brief}

The study of federalism has a long scholarly history, and studies usually involve (but are not limited to) the case studies of the U.S., Canada, Switzerland, and Germany. Definitions concerning what constitutes a federal polity are often qualified in different ways by different authors, but a general commonality is usually the central idea of a combination of self-rule and shared rule (Elazar, 1984); basically, a form of governance that balances authority between a central entity and distinct, self-contained entities. How distinct the self-contained entities are-whether described as regions, provinces, states, or simply relatively autonomous units-is the area of debate within federalist theory. Narrower definitions consider regions to be 'independent' within a federal system: "the method of dividing powers so that the general and regional governments are each, within a sphere, co-ordinate and independent" (Wheare, 1963, p. 10). The emphasis on independence, however, could potentially connote a lack of accountability to the federal level, as well as the idea of ad hoc cooperation rather than regular and formal coordination between regions, which might obscure the visibility and authority of the central government. Broader definitions such as William Riker's contextualize the independence of the region as 'autonomous' to account for the cooperation, coordination and collaboration between federal and local levels: "A Constitution is federal if (1) two levels of government rule the same land and people, (2) each level has at least one area of action in which it is autonomous, and (3) there is some guarantee (even though merely a statement in the constitution) of the autonomy of each government in its own sphere" (Riker, 1964, p. 11).

On the surface, the applicability of the term federal to both Canada and the EU seems straightforward. Canada offers a seminal example of a decentralized federal polity, with a balance of federal political authority that covers an entire country and provincial authority that is autonomous within its own policy domains. The EU offers an international example of integration of some areas of competency to the supranational level, formed by institutions whose sole purpose is to govern those policy areas delegated to the supranational level, while the domestic level retains authority on numerous areas of decision-making. Parallel to other federations (most notably the U.S.), the EU began as a group of distinct parts, whose people became citizens of the union only through their political attachment to their constituent parts-a comparison that Fabbrini refers to as the political genus "compound democracies" (Fabbrini, 2007, p. 3). The critical distinction, of course, is in the idea of statehood. Historically, federalism has been associated with state-building and integrating diverse units into nationhood (Burgess, 2012, p. 26). Canada is a single country with federalism as the trait, and an overarching 'federal' government. The EU, by contrast, is not a single state, and the institutions that comprise the supranational level operate according to what amounts to intergovernmental treaties (Moravcsik, 2007). This viewpoint holds that the areas of policy-making proscribed to the European Commission are limited and are at times subject to intergovernmental veto, while the treaties do not replace the use of a formal, conventional constitution; as well, at the public level, the absence of an intuitive idea of European citizenship all heavily limit the depth of European integration. Put roughly, the invention of European supranational institutions has not created a 'supranation'.

Nations and nationalism aside, however, the EU has many characteristics that lead scholars to comfortably group it within comparative federal polities. The major EU institutions comprise an integrated system of governance, both the motto and the practice of 'unity in diversity', and a genuine political order of structured power. The federal principle is there, if not the conventional federal state (Elazar, 1984; Haas, 1958). The absence of nationhood as described by Friedrich ("a multicentred authority, democratically legitimized and pluralistically accepting the basic fact that each citizen belongs to two communities, that of his state and that of the nation at large") (Friedrich, 1962, p. 510), or the aversion to applying the term federal to the EU (as perhaps best exemplified by the membership of the UK), becomes simply politics, rather than institutional fact. When analyzed according to behaviour in specific political situations rather than according to abstract typologies, the EU often conforms strongly to typically federal principles, as the case of CETA negotiations demonstrates. The distinction is significant for evolving paradigms of shared rule in the globalized $21^{\text {st }}$ century.

\section{Canadian Federalism in CETA}

While Canada has a relatively decentralized form of federation, the regulation of trade and commerce, and thus international trade agreements, are the sole jurisdiction of the Canadian federal government as protected by the Canadian Constitution. Although the individual provinces can and do maintain their own general foreign relations independently of the federal government-Quebec and France, for example, or Ontario's numerous delegations to other countries-the federal standing Senate Committee on Foreign Affairs and International Trade is the key decision-making and legislative body with the mandate on matters relating to international agreements and international trade (Senate of Canada, 2011). 
The style of Canadian federalism "works in the traditions of both federation and intergovernmental relations" (Baier, 2005, p. 206). The federal government maintains sole authority in trade and commerce and numerous other areas, and everything not specifically stated as belonging to the provincial levels of authority in the Constitution comes under the national Parliament (Forsey, 2012). For trade and commerce, however, the negotiation of international agreements that are increasingly more comprehensive and targeted toward regulations and other non-tariff barriers, make it more likely that commitments-and thus procedure of conducting negotiations-will be made in areas of either shared federal-provincial jurisdiction, or simply provincial jurisdiction.

"Greater participation by the provinces and territories makes the negotiation process more complex because of the level of coordination involved in developing the Canadian position. That said, cooperation should make it possible to avoid a situation in which a province or territory is opposed to the text of an agreement and would jeopardize the implementation of some of the clauses in the agreement. Because European negotiators want a CETA with Canada to include government procurement at the provincial, territorial and municipal levels and have made it a priority, consultation with the various levels of government in Canada is of even greater importance." (House of Commons, 2011)

From the outset of negotiations, European officials demanded the participation of the provinces as a device of 'pre-commitment'. This was both a reaction to previous failed attempts at agreements due to provincial unwillingness, and a necessity due to the areas of provincial jurisdiction proposed under CETA: government procurement, public services, labour mobility, and harmonization of regulations. The role of provincial jurisdiction in the realm of international trade agreements has been ambiguous with regard to constitutional law, and inconsistently applied in trade agreements. For the most part, provinces have been limited to a consultatitve role, but the intrusion of trade agreements into areas of sub-federal authority (such as agriculture, alcohol, energy) have given provinces a weightier role in the final implementation of trade agreements (Kukucha, 2011, pp. 132-133). Kukucha, writing in 2011, stated that when earlier attempts at Canada-EU trade and investment agreements fell through in 2006, the European perception was that provinces were to blame, for failing to allow Ottawa to allow the EU to make inroads on services and procurement. When Jean Charest first began contact with the EU Trade Commissioner in 2007 towards re-igniting Canada-EU trade discussion, he was told not to bother unless other provinces were on board
(Kukucha, 2011, pp. 131-132). CETA, then, became be the first large-scale trade agreement in Canada to formally include sub-national governments (Finbow, 2013, p. 2). The significance of this is both in procedure and in internal impact: procedurally, the mode of negotiation with provincial involvement created a precedent for intergovernmental federalism in the areas of trade and commerce; in terms of impact, sub-national inclusion in negotiations resulted in, if not actual greater internal policy coherence, the discussion and identification of a need for greater internal policy coherence for trade in Canada (Finbow, 2013, p. 3). The Canadian market is "fragmented" and "inhibits commitments to trading partners" as a result (Finbow, 2013, p. 3). Despite provincial regulations that inadvertently create barriers to trade, the Supreme Court of Canada has not taken an activist role in attending to such barriers as obstacles to the goal of a strong Canadian economic union. Intergovernmental politicking between provinces and the federal level are the dominant form of resolution (or attempts at) for provincial carriers. This is in direct contrast to the EU, where the European Commission under Jacques Delors pushed aggressively to complete the Single Market, and where the European Court of Justice (ECJ) played a critical role in forming and maintaining the strength of the Single Market: "As a result, the Canadian market is much less integrated than the EU one, which may seem surprising to European lawyers given that Canada is a fully-fledged federal state" (Hinarejos, 2012, p. 538).

The anticipated ratification and finalization of CET holds strong potential to significantly reshape the dynamics of Canadian federalism, in terms of a Canadian single market. The size and scope of the agreement, with all the attendant rationales for pursuing the agreement (sizable growth in Canadian exports, diversification of regional economic interdependence, access to EU single market), offer enormous leverage for policymakers and civil society alike to undertake large-scale procedural changes in order to maximize the benefits, and reduce the risks, of what CETA has to offer. Heightening the internal coherency and efficiency of the Canadian market is critical in this respect. In doing so, provinces could voluntarily reduce their autonomy to pursue divergent policies and would thus consequently bolster the power of the federal government. This would be an important departure from the principle of provincial legislative sovereignty that comes as a result of globalized liberalization: "With globalization increasingly pushing to the international level the governance of issues that were once considered solely domestic-and thus in provincial jurisdiction-Canada must be institutionally prepared to take a strong common position and ensure commitment at all levels of government to international agreements. Otherwise, we run the risk of losing our ability to interact economically and politically at the international level" (Leblond, 2010, p. 78). 


\section{The European Union and CETA}

Trade and economic relationships with external countries are one of the longest standing policies of the European Union. The 1957 Treaty of Rome held that an internal customs union required a uniform external tariff and single trade agreements with non-EC members. The six EC members at the time delegated authority for this policy area to the European institutions, effectively enabling the European Commission-responsible for agenda-setting and initiating legislation - to speak with one voice in international economic negotiations, and setting the expectation that enlargement to future members would mandate the criterion of pooling sovereignty in the same way (Woll, 2011, p. 42).

The single EU market was one of the central goals of European integration and remains, arguably, the EU's biggest achievement. The assignment of international trade agreements to the supranational level could thus be seen as unsurprising, given the early urgency for a European Economic Community. The logic of European integration sufficed to maintain support for a supranational trade policy in the face of overlap between domestic issues in the areas of health and the environment with international trade policies. Apart from the immediate relationship between an internal market and a single external trade policy, the relative success of delegation from national to EU level is noteworthy in the context of comparative federalism, not in the least when compared to Canada.

The rules governing trade policy in the EU are laid out in Article 207 of the Treaty on the Functioning of the EU (TFEU) within the 2009 Lisbon Treaty; this treaty extended the ordinary legislative procedure to the area of trade, and created a Foreign Affairs Council that is also responsible for trade (European Commission, 2015). The European Commission, the executive institution of EU governance that is responsible for representing the interests of Europe as a whole (as opposed to the interests of individual member states), is responsible for setting the agenda and conducting negotiations as the sole representative of the EU, after receiving authorization from the Council. The Commission reports regularly to both the Council and the European Parliament throughout the course of negotiation (European Commission, 2015). The intergovernmental General Affairs Council of Foreign Ministers decides on the negotiation objectives on the basis of a Commission proposal, and ultimately approves the results through the ordinary legislative procedure. ${ }^{5}$ When the Foreign Affairs Council attends

5 The Ordinary Legislative Procedure of the EU, sometimes referred to as the 'Community Method' and previously referred to as 'codecision', is the style of policy-making whereby the Commission submits a proposal to the European Parliament (also a supranational institution) and the Council of to issues concerning international trade, it is chaired by the country holding the rotating presidency. This secures the balance of power between governmental levels; the Commission initiates the trade strategy, but the member states must approve the strategy. The scope of the Commission's executive power covers not just trade in goods, but also trade in services, intellectual property, foreign direct investment, transport, and capital movements (European Commission, 2013; Woolcock, 2011, p. 27).

The 1986 Single European Act introduced qualified majority voting within the European Council on single market policies (as opposed to unanimity voting, which was the previously used method for internal market legislation) which helped streamline the process toward achieving the single market, as it removed the possibility for a single member state to enact veto power in moving market integration forward (Dinan, 2004; European Commission, 2014). Prior to the single market, the 1979 ECJ ruling in Cassis de Dijon smoothed the way forward for the free movement of goods within the internal market. The case introduced the principle of 'mutual recognition', where if a product was available freely for sale in one member state then it must be allowed to do so in all member states. The principle of supremacy, where EU law ultimately trumps national law, protected the notion of mutual recognition and prevented member states from enacting egregious protections to restrict the free movement of goods (Dinan, 2004). The single internal market of the EU reached completion in 1992, with the (Maastricht) Treaty on European Union. This allowed for the removal of barriers toward the free movement of goods, services, people, and capital among all EU member states.

The degree to which member states have control over single market and external trade policies relates to both the executive authority of the Commission in these policy areas and the central idea of subsidiarity within the EU project. To the former, the institutional component of "autonomy by design" intentionally insulated the Commission from domestic political pressures in order to achieve internal trade liberalization: "all authors within this literature strand concur that the role of the supranational institutions in EU trade policy goes beyond pure intergovernmental decision-making" (Woll, 2011, pp. 43-44). To the latter, an essential concept within the current legal framework of the EU treaties is the principle of subsidiarity, which ensures that decisions should be taken as closely as possible to the citizen and that the Union is justified in its actions in light of the possibilities available at the

the EU (the intergovernmental institution comprised of national leaders). A formal process of consultation, revision, and either adoption or dismissal proceeds between the three institutions (Dinan, 2004). 
national, regional, or local levels (Dinan, 2004). The legality of this framework strikes an effective balance between competency and feedback and helps confirm that the interests of member states are driving trade policy as a whole: "Delegation is thus accompanied by a long list of formal and informal control mechanisms, as principal-agent analysis suggests and that many analysts have confirmed in the context of EU trade policy" (Woll, 2011, p. 44).

The push for a trade agreement with Canada came largely from Canadian businesses and policy makers, but had strong support in numerous EU members, beginning with the German Council Presidency in the latter half of 2007 (Hübner, 2011, p. 1). The main incentives for the EU in pursuing CETA had to do with access to a major industrialized market, access to energy and resource markets, enhancing revenue for businesses and exporters, and, arguably, using Canada as a 'stepping-stone' to pursue a similar free trade agreement with the much larger U.S. To the last point, the ability of the EU to negotiate a comprehensive agreement with a developed democracy, with notable successes in non-tariff areas (such as services, investment, and public procurement) represented a significant success juxtaposed against the failed WTO Doha Round, of which the EU had championed. Any specific areas of interest or concern with CETA itself came less from the actual member states and more from businesses or the European Parliament (EP). Exporters and the private sector were generally consistently enthusiastic (Irish Exporters Association, 2013), and the EP was effective in asserting European demands and concerns (Waldie, 2013, on the EP and pharmaceutical drugs). While the perceived ease in achieving consensus among member states towards CETA could be attributed to the amount of leverage the EU had in negotiations - the EU being the greater market, and with less existing reliance on trade with Canada-it can also be argued that the institutional design of the single market and external trade policies contributed to the overall lack of objection, disunity, or suspicion toward the construction of CETA. One important exception to this was the Czech Republic's concern over the visa requirement toward Czech citizens traveling to Canada; the visa requirement was removed during the final round of CETA talks in late 2013 (Wingrove, 2013). Aside from this, the process of CETA negotiations remained remarkably less contentious in the EU than in Canada.

\section{Comparative Federalism or Comparative Intergovernmentalism?}

What do the CETA negotiations to date tell us about regional integration, and about federalism as a trait or a process? To begin with, regional integration is increasingly becoming a rational method of responding to the challenges of globalization, as evidenced through economic trade blocs and partnerships (Van Langenhove \& Scaramagli, 2012). In the case of CETA, regional integration can be understood in three ways: the single market of the EU as European regional integration; the commitment to transatlantic interdependence in CETA itself; and, the potential for deeper inter-provincial integration within the Canadian market as a means of responding to CETA. The latter dynamic is arguably the most significant in terms of the visibility of what the EU can accomplish through norms as well as through material resources. The strength of the EU single market gave it an enormous amount of leverage in CETA dynamics. The institutional model supporting the EU's single market-that of clearly delegated authority to centralized governance, and an internal market that has already effectively removed barriers between EU members for trade, services, and investment-became increasingly relevant as the EU Commission was able to secure the 'pre-commitment' of the Canadian provinces before beginning negotiations. In effect, the supranational example became the dominant example of how separate markets ought to deal with one another.

In the limited realm of external free trade policies, the EU is a stronger example of procedural federalism than Canada, if federalism is partly understood by internal coherency within the framework of 'unity in diversity'. The lack of the federal-nation trait in the EU is, in this policy realm, compensated for by the intentionality of European integration. The strict parameters of the Ordinary Legislative Method, the principles of subsidiarity and proportionality, the central goal of the single market, and the strong legal activism of the ECJ all combine to make the single economic union less fragmented in the EU than in Canada, and as a result, the process of negotiating free trade agreements less problematic than in Canada. Provincial barriers between the full free movement of goods, services, labour and capital are such that the EU's single market has more fluidity than the Canadian market, which in turn has helped the supranational level become the logical area of delegation for external trade decisions. While the corresponding Canadian procedure for trade negotiations is similar at the federal level, the internal dynamics between provincial and federal governments is less explicit. This is the result of a more fragmented internal market and less intrusion into provincial protectionism by the court system.

However, the difference between internal regulations of economic unions does not alone define the quality of federalism. Canada remains a definitive federal polity, heavily decentralized and with a strong federal level. Its provinces are not sovereign nationstates, and the federal idea is concretely imbued into Canadian politics, governance, and discourse. By contrast, the executive authority of the European 
Commission is not a federal government, and the regions firmly remain sovereign, independent countries. The EU offers numerous examples of federal traits, but because it is not a nation it lacks the normative commitment to social solidarity typically found in federal nations (Hueglin, 2013, p. 191). The distinction presents an interesting paradox when considering CETA; the cautious integration of sovereign nations within the EU has resulted in intentional pooling of authority at the supranational level for reasons secondary to the single market, while the birth of a Canadian federal dominion under the 1867 British North America Act/Constitution Act established the nation before more recent conceptions of inter-provincial policy autonomy. The more explicit principle of subsidiarity in the EU, combined with qualified majority voting in single market policy, has set a structured course for free trade agreements-one that is likely to be mimicked elsewhere.

The better point might be the idea of comparative intergovernmentalism. Instead of the debates over what reasonably constitutes an entity to be considered in the comparative federal context, a complementary route is to compare the two blocs on the basis of their internal institutional dynamics. Precisely because of its supranational 'non-state' character, the EU is in many ways better institutionally equipped to introduce new agreements or arrangements that attend to the multilateral nature of economic globalization (i.e., subsidiarity, ordinary legislative procedure, qualified majority voting). Procedure and agenda-setting is the direct result of improving upon the logic of integration in a manner that assuages national interests. Canada, by contrast, is clunkier in this regard, but only insomuch as the comparison is with free trade negotiations. CETA offered the first precedent of sub-national governments being included, and with it came inter-provincial debate over the stipulations of CETA. The balance between decentralization and the federal government in Canada has strong parallels with the ordinary legislative procedure in the EU: "power allocations in Canada and the EU are not so far apart at all once the conceptual framework of federalism with its presumption of watertight divisions of powers is replaced by one emphasizing power sharing through intergovernmental cooperation and agreements." (Hueglin, 2013, p. 193) The idea of intergovernmentalism, with its connotations of cooperation through mutual deliberation, offers a better comparative platform for the EU and Canada than broad or narrow dimensions of federalism.

\section{Conclusion}

The first conclusion is that the CETA represents a watershed in international trade agreements for three reasons: for the breadth and width of areas subject to barrier removal and deregulation; for the precedent set in transatlantic cooperation; and for the dynamics of policy-making between two very different federalstyle political entities. Traditionally, analyses of federal governance have held Canada to be emblematic of a federal state and the EU to be a heavily qualified outlier. Narrowing the focus on international trade negotiations shows that the balance between self-rule and sharedrule and the division of powers between centre and regions is a less problematic process in the EU due to the deliberate internal coherency of the single market. In Canada, the inclusion of sub-national governments in the free trade negotiation process from the outset worked against past procedure and required restructuring of policy-making. Considering the two entities as two forms of intergovernmentalist polities - rather than two diverse examples of federalism-gives more nuance to comparing the institutional properties of both areas.

There are two important caveats to this argument. The first caveat is the imbalance of leverage between Canada and the EU; for Canada, CETA offers many more benefits and access to the huge European market, while for the EU the benefits are to a smaller degree. Whether the same degree of smooth delegation and cooperation between EU member states will continue in ongoing Transatlantic Trade and Investment Partnership (TTIP) discussions with the U.S.whose market size parallels the EU, and thus whose access offers exponentially more possibilities and controversies-remains to be seen. The second caveat is the recognition that civil society and the private sector may have just as much sway over free trade negotiations in either area than provincial governments or member states. The role of business chambers and employer associations on either side of the Atlantic has undoubtedly played a major role in pushing for trade liberalization and/or special considerations for specific sectors - a factor that should be accounted for so as not to over-attribute the dynamics between regional and centre governmental institutions.

The second conclusion is the implication resulting from the comparison of CETA negotiations in Canada and the EU; namely, the principle of subsidiarity in the EU setting, and the success of EU in exporting this principle to the federal decision-making system in Canada. At the outset of CETA discussions, the Commission asserted that Canadian provinces would have to be consulted throughout the process in order for the EU to begin proceedings. The compliance of the Canadian government in this new precedent in part highlights the ability of the EU to export European-style federal norms to other places. In this regard, the federal character of the EU might hold more relevance for the present context of economic globalization than for past theories of federalism.

\section{Acknowledgments}

This paper was originally presented at the Western Po- 
litical Science Association (WPSA) Annual Meeting in Seattle, WA, 2014 (Panel 01.18: Regional Integration and Intergovernmental Politics). The author would like to thank the panel's discussant for the feedback, as well as the anonymous reviewers for their invaluable suggestions.

\section{Conflict of Interests}

The author declares no conflict of interests.

\section{References}

Baier, G. (2005). The EU's constitutional treaty: Federalism and intergovernmental relations-Lessons from Canada. Regional \& Federal Studies, 15(2), 205-223.

Burgess, M. (2012). Federalism. In A. Wiener \& T. Diez (Eds.), European integration theory (2nd ed.) (pp. 2544). Oxford, UK: Oxford University Press.

Dinan, D. (2004). Europe recast: A history of European Union. Boulder, CO: Lynne Rienner.

Elazar, D. J. (1984). Federalism and political integration. Lanham, MD: University Press of America.

Elazar, D. J. (1995). From statism to federalism: A paradigm shift. Publius, 25(2), 5-18.

European Commission. (2013). Countries and Regions. Canada. European Commission. Retrieved from http://ec.europa.eu/trade/policy/countries-andregions/countries/canada

European Commission. (2014). The European Single Market. European Commission. Retrieved from http://ec.europa.eu/internal_market/top_layer/mon itoring/governance_en.htm

European Commission. (2015). What is trade policy? European Commission. Retrieved from http://ec.euro pa.eu/trade/policy/policy-making

European Commission, \& Government of Canada. (2008). Assessing the costs and benefits of a closer EU-Canada economic partnership. Government of Canada, Global Affairs Canada. Retrieved from http://trade.ec.europa.eu/doclib/docs/2008/october /tradoc_141032.pdf.

Fabbrini, S. (2007). Compound democracies: Why the United States and Europe are becoming similar. Oxford: Oxford University Press.

Finbow, R. (2013). CETA and multi-level governance: Implications for provincial and municipal governments. Canada-Europe Transatlantic Dialogue, CETA Policy Briefs Series. Retrieved from http://labs.carleton.ca/ canadaeurope/wp-content/uploads/sites/9/FINBOW _CETD_CETA-and-Multi-Level-governance.pdf

Forsey, E. A. (2012). How Canadians govern themselves. Parliament of Canada. Retrieved from http://www. parl.gc.ca/about/parliament/senatoreugeneforsey/b ook/chapter_3-e.html

Friedrich, C. J. (1962). Federal constitutional theory and emergent proposals. In A. W. Macmahon (Ed.), Fed- eralism: Mature and emergent (pp. 510-533). New York, NY: Russell \& Russell.

Gauthier, A., \& Holden, M. (2010). Canada-European Union trade negotiations 1. Overview of negotiations. (Publication No. 2010-53 E). Ottawa, Canada: Library of Parliament. Retrieved from http://www. lop.parl.gc.ca/content/lop/ResearchPublications/201 0-53-e.htm.

Government of Canada. (2013). Trade negotiations and agreements. Government of Canada. Retrieved from http://www.canadainternational.gc.ca/eu-ue/policie s-politiques/trade_agreements-accords_commerciau $\mathrm{x} . \mathrm{aspx}$

Haas, E. B. (1958). The uniting of Europe: Political, social, and economic forces 1950-57. Stanford, CT: Stanford University Press.

Hinarejos, A. (2012). Free movement, federalism, and institutional choice: A Canada-EU comparison. Cambridge Law Journal, 71(3), 537-566.

House of Commons. (2011). Negotiations toward a comprehensive economic and trade agreement (CETA) between Canada and the European Union. CIIT (41-1). Retrieved from http://www.parl.gc.ca/House Publications/Publication.aspx?Docld=5431905\&Lang uage $=$ E \&Mode $=1 \&$ Parl $=41 \&$ Ses $=1 \&$ File $=87$

Hübner, K. (2011). Canada and the EU: Shaping transatlantic relations in the twenty-first century. In $\mathrm{K}$. Hübner (Ed.), Europe, Canada and the comprehensive economic and trade agreement (pp. 1-18). New York, NY: Routledge.

Hueglin, T. (2013). Treaty federalism as a model of policy making: Comparing Canada and the European Union. Canadian Public Administration, 56(2), 185-202.

Irish Exporters Association. (2013). Ireland has most to gain from the EU-Canada comprehensive economic and trade agreement (CETA). Irish Exporters Association. Retrieved from http://www.irishexporters.ie/ ireland-has-most-to-gain-from-the-eu-canada-compr ehensive-economic-and-trade-agreement-ceta

Kukucha, C. (2011). Provincial pitfalls: Canadian provinces and the Canada-EU trade negotiations. In K. Hübner (Ed.), Europe, Canada and the comprehensive economic and trade agreement (pp. 130-150). New York, NY: Routledge.

Leblond, P. (2010). The Canada-EU comprehensive economic trade agreement: More to it than meets the eye. Policy Options. Retrieved from http://policy options.irpp.org/issues/immigration-jobs-and-canad as-future/the-canada-eu-comprehensive-economictrade-agreement-more-to-it-than-meets-the-eye

Moravcsik, A. (2007). The European constitutional settlement. In S. Meunier \& K. R. McNamara (Eds.), The state of the European Union volume 8. Making history: European integration and institutional change at fifty (pp. 23-50). Oxford, UK: Oxford University Press.

Riker, W. H. (1964). Federalism: Origin, operation, significance. Boston, MA: Little Brown and Company. 
Senate of Canada. (2011). About the committee. Introduction to the standing senate committee on foreign affairs and international trade. Parliament of Canada. Retrieved from http://www.parl.gc.ca/sencomm itteebusiness/CommitteeAbout.aspx?parl=41\&ses=1 \&Language $=E \&$ comm_id=8

Van Langenhove, L., \& Scaramagli, T. (2012). Regional integration as a response to globalization. In J. Heine \& R. Thakur (Eds.), The dark side of globalization (pp. 191-207). Tokyo, Japan: UNU Press.

Waldie, P. (2013, October 18). Canada, EU unveil 'historic' free-trade agreement. The Globe and Mail. Retrieved from http://www.theglobeandmail.com/ news/politics/eu-harper/article14924915

Wheare, K. C. (1963). Federal government. Oxford, UK: Oxford University Press.

Wingrove, J. (2013, November 14). Canada lifts Czech travel visa, smoothing wrinkle in EU trade deal. The Globe and Mail. Retrieved from http://www.the globeandmail.com/news/politics/canada-lifts-czechtravel-visa-smoothing-wrinkle-in-eu-trade-deal/articl e15440977

Woll, C. (2011). Who scripts European trade policies? Business-government relations in the EU-Canada partnership negotiations. In K. Hübner (Ed.), Europe, Canada and the comprehensive economic and trade agreement (pp. 41-58). New York, NY: Routledge.

Woolcock, S. B. (2011). European Union trade policy: The Canada-EU comprehensive economic and trade agreement (CETA). Towards a new generation of FTAs? In K. Hübner (Ed.), Europe, Canada and the comprehensive economic and trade agreement (pp. 21-40). New York, NY: Routledge.

World Trade Organization, International Trade Centre, \& United Nations Conference on Trade and Development. (2015). World Tariff Profiles 2015. Retrieved from https://www.wto.org/english/res_e/booksp_e/ tariff_profiles15_e.pdf

\section{About the Author}

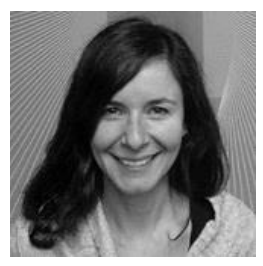

Valerie D'Erman is a postdoctoral fellow at the University of Victoria, working on a project entitled "The Politics of the Euro Crisis" and teaching several courses in Political Science and the European Studies program. She holds a Ph.D. in Comparative Politics from the University of Oklahoma. Her research focuses on European integration, comparative political economy, European social dialogue, and transatlantic relations. 